\title{
High throughput screening of hydrolytic enzymes from termites using a natural substrate derived from sugarcane bagasse
}

\author{
Severino A Lucena', Leile S Lima', Luís SA Cordeiro Jr' ${ }^{1}$, Celso Sant'Anna' ${ }^{1}$, Reginaldo Constantino², \\ Patricia Azambuja ${ }^{3,4}$, Wanderley de Souza', Eloi S Garcia ${ }^{1,3,4}$ and Fernando A Genta ${ }^{3,4^{*}}$
}

\begin{abstract}
Background: The description of new hydrolytic enzymes is an important step in the development of techniques which use lignocellulosic materials as a starting point for fuel production. Sugarcane bagasse, which is subjected to pre-treatment, hydrolysis and fermentation for the production of ethanol in several test refineries, is the most promising source of raw material for the production of second generation renewable fuels in Brazil. One problem when screening hydrolytic activities is that the activity against commercial substrates, such as carboxymethylcellulose, does not always correspond to the activity against the natural lignocellulosic material. Besides that, the macroscopic characteristics of the raw material, such as insolubility and heterogeneity, hinder its use for high throughput screenings.

Results: In this paper, we present the preparation of a colloidal suspension of particles obtained from sugarcane bagasse, with minimal chemical change in the lignocellulosic material, and demonstrate its use for high throughput assays of hydrolases using Brazilian termites as the screened organisms.

Conclusions: Important differences between the use of the natural substrate and commercial cellulase substrates, such as carboxymethylcellulose or crystalline cellulose, were observed. This suggests that wood feeding termites, in contrast to litter feeding termites, might not be the best source for enzymes that degrade sugarcane biomass.
\end{abstract}

Keywords: bagasse, cellulase, enzyme, hemicellulase, hydrolysis, sugarcane, termite

\section{Background}

Cellulose is the most abundant biopolymer on earth, synthesized by plants at a rate of approximately $10^{11}$ to $10^{12}$ tons per year [1]. Lignocellulosic resources comprise a promising alternative to fossil fuels and, in the context of the global warming crisis, the need to find ways of converting these materials into usable forms of energy has become of paramount importance and may have strong socioeconomic implications, especially in developing tropical countries [2].

In Brazil, the most promising lignocellulosic resource for biofuel production is sugarcane bagasse [3]. Bagasse is a byproduct of sugar and alcohol production, obtained

\footnotetext{
* Correspondence: genta@ioc.fiocruz.br

${ }^{3}$ Laboratory of Insect Biochemistry and Physiology, Oswaldo Cruz Institute, Avenida Brasil 4365, Leônidas Deane Building Room 207, Rio de Janeiro, 21040-360, Brazil

Full list of author information is available at the end of the article
}

after the milling of the sugarcane stalk, and is currently burned by the refineries. However, research is being carried out on the hydrolysis and fermentation of sugarcane bagasse for the production of ethanol - the most important biofuel for cars in the country [4]. Techniques for pretreatment of this material by steam explosion, organosol, auto-hydrolysis, acid hydrolysis, alkaline hydrogen peroxide and alkaline extraction are being used in the so-called second generation ethanol refineries [5]. After pretreatment, the material is subjected to enzymatic treatments, and the hydrolyzed products are fermented to produce ethanol [6]. Therefore, the discovery of new enzymes with hydrolytic activity suitable for this kind of lignocellulosic material is extremely important.

One major concern with the use of commercial preparations of enzymes is that the activity detected using
C Biomed Central

() 2011 Lucena et al; licensee BioMed Central Ltd. This is an Open Access article distributed under the terms of the Creative Commons Attribution License (http://creativecommons.org/licenses/by/2.0), which permits unrestricted use, distribution, and reproduction in any medium, provided the original work is properly cited. 
commercial or synthetic substrates does not necessarily reflect the activity on the natural source of the lignocellulosic material to be used. The use of a natural source of biomass for high throughput screenings is hindered by the presence of gross and insoluble particles. The utilization of a milled particle slurry for enzymatic assays with corn stover has already been proposed [7]. However, in this case the suspension was obtained after extensive physicochemical treatments of the raw material, which makes its preparation expensive and could have altered the biochemical properties of the substrate, and its reactivity to certain enzymes.

In this paper, we present a new substrate, colloidal sugar cane bagasse (CSCB), and asses it's suitability for screening hydrolases and for the characterization of enzymes from Brazilian termites; these enzymes have not yet been studied. A colloidal substrate was obtained with minimal pretreatment of the raw material, which makes the protocol cheap and suitable for high throughput screening of hydrolases.

Our group is carrying out an extensive screening of hydrolases from different organisms, ranging from bacteria and fungi to invertebrates. In this work we present the results obtained from screening invertebrate enzymes, focusing on Brazilian termites. Wide screenings of insect enzymes for biotechnological applications have been already published [8], but they are focused only on cellulase activities, using commercial substrates such as carboxymethylcellulose (CMC) or Avicel. Herein, we show a screening of termite activities with new specificities included (such as hemicellulases, xylanases and pectinases) and also show that the use of raw biomass as a substrate can reveal unexpected results. From among the termites screened, Spinitermes nigrostomus had the most promising activity against sugarcane bagasse. This shows that termites with non-wood feeding habits can also be an interesting source of enzymes for the digestion of lignocellulosic materials from sugarcane.

\section{Results and discussion}

\section{Preparation and characterization of CSCB}

After dry milling, sieving and wet milling (see Materials and methods), sugarcane bagasse is transformed into a brown and homogeneous suspension of fine particles (not shown). The suspension is not affected by autoclaving or freezing in terms of reactivity to commercial cellulolytic enzymes, and can be kept at $4{ }^{\circ} \mathrm{C}$ for at least 6 months (not shown). The particles can be pelleted by centrifugation, dried by lyophilization and resuspended without loss of reactivity (not shown). However, sonication of the suspension results in a significant loss of reactivity to Trichoderma reesei cellulase $(19 \pm 2 \%$, mean \pm standard error of the mean (SEM) of three replicates).
Due to its homogeneous appearance, the suspension was named CSCB. An inspection of CSCB particles with transmission electron microscopy revealed that their size is in the micrometer range, with an average diameter of $6.0 \pm 0.3 \mu \mathrm{m}$ (mean $\pm \mathrm{SEM}$ ). The size distribution of the particles is quite broad (Figure 1A), with diameters ranging from $1 \mu \mathrm{m}$ to $40 \mu \mathrm{m}$, and $56 \%, 36 \%$, $7 \%$ and $1 \%$ of particles with diameters between $0 \mu \mathrm{m}$ to $5 \mu \mathrm{m}, 5 \mu \mathrm{m}$ to $15 \mu \mathrm{m}, 15 \mu \mathrm{m}$ to $25 \mu \mathrm{m}$ and $>25 \mu \mathrm{m}$, respectively. An inspection of the particles with scanning electron microscopy revealed irregular shapes (Figure $1 \mathrm{~B}$ ). These features are consistent with the mild treatment and structural heterogeneity of the original material.

We were able to obtain $1.6 \mathrm{~L}$ of CSCB from $40 \mathrm{~g}$ of sugarcane bagasse, with a total sugar concentration of $2.8 \pm 0.6 \%(\mathrm{w} / \mathrm{v})$ (three replicates). Considering that it is possible to scale down hydrolytic assays, using $25 \mu \mathrm{L}$ of CSCB (see below), it is possible to perform approximately 64,000 assays with a single batch of CSCB, with a low cost of US\$ 0.30 per enzymatic assay. Considering the stability of the CSCB preparation and the possibility for the distribution of commercial preparations of the autoclaved suspension or of the lyophilized powder, it was deposited in the National Institute of Industrial Property of Brazil (patent number 020110064559).

\section{Standard enzymatic assays with commercial enzyme preparations}

Before use in the screening of hydrolytic activity, the CSCB hydrolysis assay conditions were established using a commercial preparation of cellulase from $T$. viride. The release of reducing sugars from CSCB was determined with dinitrosalicylic acid, because detection with bicinchoninic acid resulted in very high background

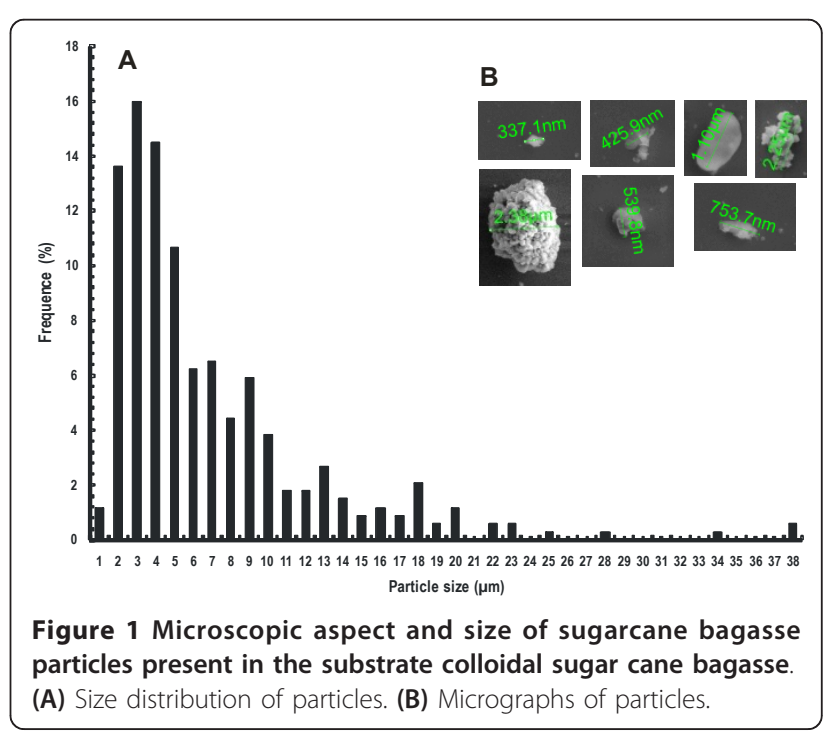


absorbances (data not shown). This could be due to the presence of proteins in $\mathrm{CSCB}$, and the high reactivity of this reagent to polypeptides [9].

The activity of $T$. viride cellulase against CSCB could be detected within short incubation times (Figure 2). Linear assays (Figure 2) were obtained even without constant mixing of reagents, and the dispersion of the suspension was stable in this condition (not shown). However, assays performed over 2 hours or longer (see below) needed constant stirring during the incubations.

The activity of $T$. viride against CSCB was similar to the activity of this enzyme against commercial substrates such as Avicel or CMC (Table 1 and Figure 2), suggesting that cellulose, which is recognized by this enzyme, is the major component of CSCB. This is consistent with the report that cellulose constitutes approximately $40 \%$ $(\mathrm{w} / \mathrm{w})$ of sugar cane bagasse [10]. Comparative analysis of activities from different animal sources against CSCB (see below) reinforces this hypothesis, even with the presence of different enzyme specificities in our commercial cellulase sample (see Table 1). Additionally, the activities measured here with CSCB and other substrates (approximately $0.2 \mathrm{U} / \mathrm{mg}$ ) using the $T$. viride enzyme have the same order of magnitude as the activities described for this source of cellulase acting on filter paper $(0.5 \mathrm{U} / \mathrm{mg}$ of protein to $1 \mathrm{U} / \mathrm{mg}$ protein) [11].

The impact of using different CSCB preparations for enzyme assays was assessed in three distinct batches of this substrate with the same sample of the commercial T. viride cellulase. The replicates showed similar results (Figure 3), indicating that, in spite of being a biological

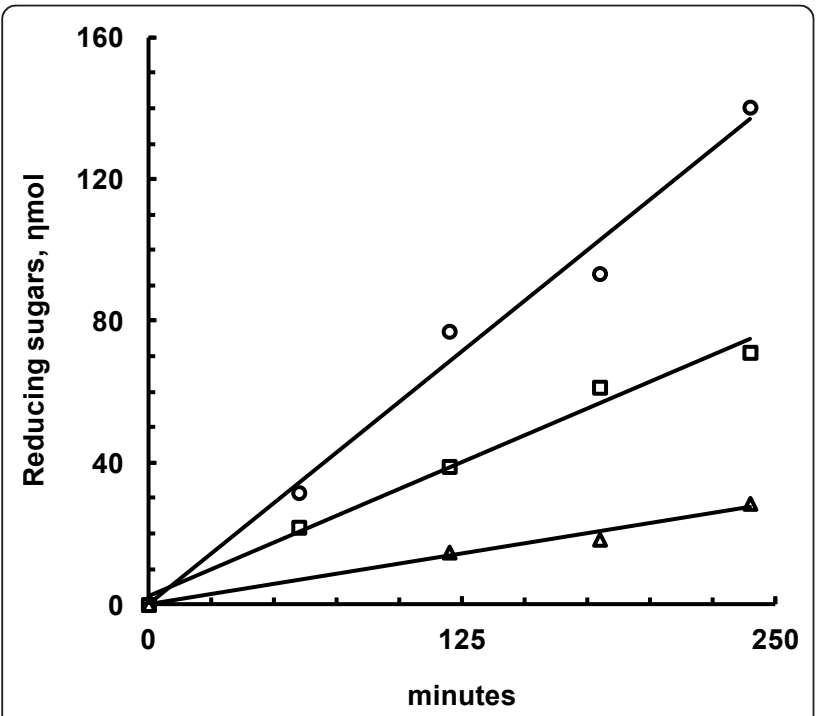

Figure 2 Enzymatic assays (reducing sugars versus time) with a commercial preparation of $T$. reesei cellulase against various substrates. Circles: colloidal sugar cane bagasse; squares: Avicel; triangles: carboxymethylcellulose.
Table 1 Activities measured against different substrates and colloidal sugar cane bagasse in a commercial preparation of cellulase from Trichoderma reesei.

\begin{tabular}{lll}
\hline Substrate & $\begin{array}{l}\text { Enzymatic activity } \\
(\mathbf{m U} / \boldsymbol{\mu L})\end{array}$ & $\begin{array}{l}\text { Specific activity } \\
(\mathbf{m U} / \mathbf{m g})\end{array}$ \\
\hline Laminarin & $0.049 \pm 0.002$ & $290 \pm 30$ \\
CMC & $0.010 \pm 0.001$ & $59 \pm 8$ \\
Pectin & $0.0008 \pm 0.0001$ & $5 \pm 1$ \\
Xylan & $0.034 \pm 0.002$ & $210 \pm 20$ \\
pnPßGlu & $0.020 \pm 0.001$ & $120 \pm 10$ \\
pnPßXyl & $0.013 \pm 0.001$ & $81 \pm 9$ \\
Avicel & $0.015 \pm 0.001$ & $90 \pm 10$ \\
CSCB & $0.032 \pm 0.002$ & $190 \pm 21$ \\
\hline
\end{tabular}

Protein concentration was $0.17 \pm 0.01 \mathrm{mg} / \mathrm{mL}$. Numbers are means \pm standard error of the mean from five experiments. See Materials and methods for more details. CMC: carboxymethylcellulose; CSCB: colloidal sugar cane bagasse; pnP $\beta$ Glu: $p$-nitrophenyl- $\beta$-glucoside; $p N P \beta X y l$ : p-nitrophenyl- $\beta$-xyloside.

material with a high degree of heterogeneity, CSCB could provide reproducible measurements of hydrolytic activity. This probably reflects the fact that the cellulose content of distinct batches of sugarcane bagasse does not vary very strongly [10].

The simplicity, cheap cost and miniaturization of the short term assays with CSCB indicate that this substrate could be used in the future for monitoring enzyme activity in commercial preparations, before its use on an industrial scale. This is a major concern for producers of second generation ethanol from sugarcane bagasse; the development of CSCB is part of an effort to standardize this productive chain.

\section{The use of CSCB for the screening of hydrolases}

To test the usability of CSCB in routine screenings of hydrolytic activities in field samples, we used this substrate to monitor activities of the gut homogenate of different Brazilian termites. These animals are being subjected to intense biochemical and molecular biological research by our group as a potential source of new enzymes for use in the enzymatic hydrolysis of sugarcane bagasse. Here, we present the first results of using CSCB for enzyme screening in biological samples.

Because some termite preparations have very limited amounts of protein and activity, we used longer incubation times (up to 24 hours) for these samples, but CSCB suspension was not fully stable under these conditions. Thus, for termite samples, we performed assays in 96deepwell plates with a small magnetic bar in each well, for stirring during incubation (see Materials and method section for details).

All assays of termite guts performed with CSCB showed linearity of product formation with time (Figure 4 ), which indicates that CSCB is suitable for the measurement of the initial rate of hydrolysis in these 


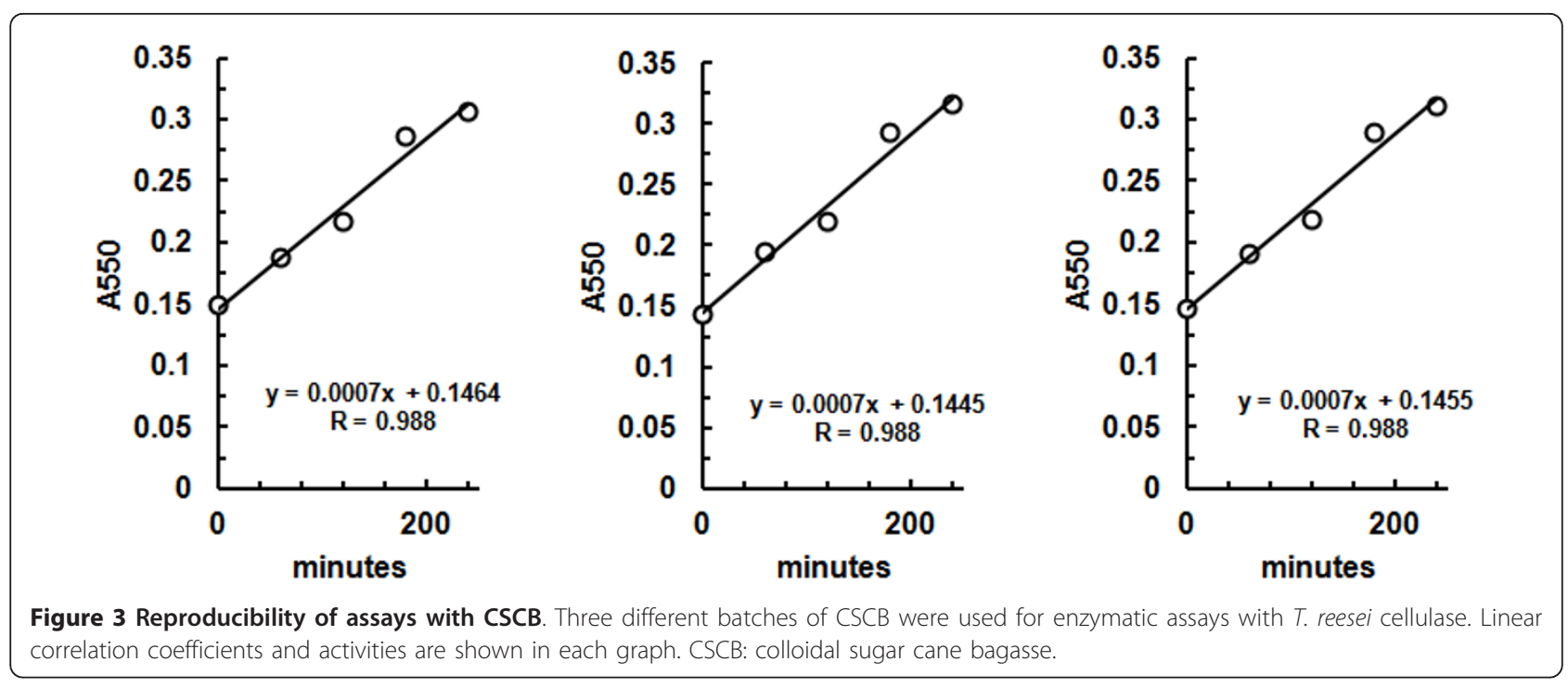

samples. Similar results were obtained with CMC or cellulose (Figure 4).

The hydrolytic activities against CSCB with termite gut homogenates are comparable with the activities observed when commercial substrates, such as CMC, cellulose or $\mathrm{p}$-nitrophenyl- $\beta$-glucoside ( $\mathrm{pnP} \beta \mathrm{Glu}$ ), are used (Table 2). Interestingly, the termite species with the highest activity against CSCB, Spinitermes nigrostomus, is not a typical wood feeder, being classified as a detritivore [12]. Species with the highest activities against classical cellulase substrates, that is, CMC (Nasutitermes jaraguae and N. bivalens) and cellulose

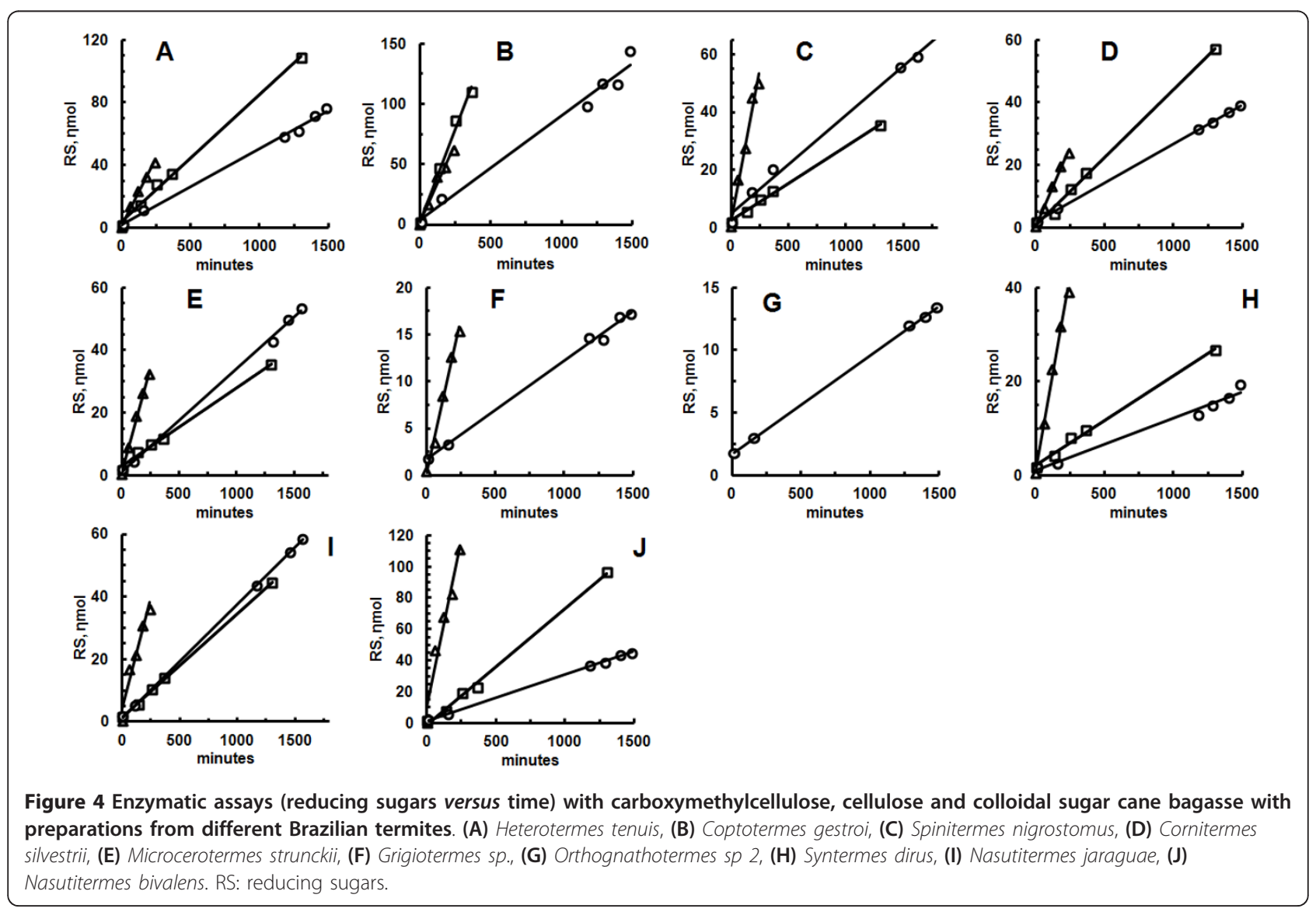


Table 2 Activities against different substrates (including CSCB) and protein content in termites.

\begin{tabular}{|c|c|c|c|c|c|c|c|c|c|}
\hline \multicolumn{10}{|c|}{ Activities (mU/animal); specific activities in parentheses $(\mathrm{mU} / \mathrm{mg}$ protein) } \\
\hline Species & Laminarin & CMC & Pectin & Xylan & Cellulose & pNPBGlu & pNPßXyl & CSCB & Protein (mg/animal) \\
\hline \multirow[t]{2}{*}{ H. tenuis } & $0.20 \pm 0.02$ & $0.070 \pm 0.004$ & $0.11 \pm 0.01$ & $0.28 \pm 0.04$ & $1.3 \pm 0.1$ & $2.4 \pm 0.1$ & $0.36 \pm 0.02$ & $0.19 \pm 0.02$ & $0.10 \pm 0.01^{a, b}$ \\
\hline & $(2.2 \pm 0.2)^{a, b}$ & $(0.77 \pm 0.07)^{a}$ & $(1.3 \pm 0.2)^{a}$ & $(3.0 \pm 0.4)^{a}$ & $(14 \pm 2)^{a}$ & $(40 \pm 2)^{d}$ & $(6.2 \pm 0.3)^{a}$ & $(2.2 \pm 0.3)^{a}$ & \\
\hline \multirow[t]{2}{*}{ C. gestroi } & $0.49 \pm 0.05$ & $0.14 \pm 0.02$ & $0.28 \pm 0.07$ & $0.55 \pm 0.09$ & $1.6 \pm 0.2$ & $7.3 \pm 0.3$ & $0.84 \pm 0.08$ & $0.43 \pm 0.02$ & $0.09 \pm 0.01^{a, b}$ \\
\hline & $(6.2 \pm 0.6)^{a, b, c}$ & $(1.6 \pm 0.3)^{a}$ & $(3.6 \pm 0.9)^{a}$ & $(7 \pm 1)^{a, b}$ & $(17 \pm 2)^{a}$ & $(94 \pm 3)^{f}$ & $(11 \pm 1)^{a}$ & $(4.7 \pm 0.8)^{a}$ & \\
\hline \multirow[t]{2}{*}{ Grigiotermes sp. } & $2.7 \pm 0.2$ & $0.32 \pm 0.04$ & $0.27 \pm 0.04$ & $0.15 \pm 0.04$ & $0.022 \pm 0.008$ & $2.3 \pm 0.1$ & $2.29 \pm 0.08$ & $0.07 \pm 0.01$ & $0.14 \pm 0.02^{c}$ \\
\hline & $(19 \pm 5)^{d, e}$ & $(2.2 \pm 0.8)^{a}$ & $(1.8 \pm 0.5)^{a}$ & $(0.8 \pm 0.3)^{a}$ & $(0.20 \pm 0.07)^{b}$ & $(57 \pm 5)^{e}$ & $(58 \pm 4)^{c}$ & $(0.45 \pm 0.05)^{a}$ & \\
\hline \multirow[t]{2}{*}{ S. nigrostomus } & $2.0 \pm 0.2$ & $1.06 \pm 0.06$ & $1.0 \pm 0.2$ & $1.4 \pm 0.2$ & $0.17 \pm 0.04$ & $2.4 \pm 0.2$ & $0.12 \pm 0.02$ & $0.930 \pm 0.009$ & $0.09 \pm 0.01^{a, b}$ \\
\hline & $(22 \pm 1)^{\mathrm{e}}$ & $(11.7 \pm 0.6)^{b}$ & $(11 \pm 2)^{b}$ & $(16 \pm 3)^{b}$ & $(2.3 \pm 0.5)^{b}$ & $(33 \pm 4)^{c, d}$ & $(1.2 \pm 0.5)^{a}$ & $(13 \pm 3)^{b}$ & \\
\hline \multirow[t]{2}{*}{ M. strunckii } & $0.030 \pm 0.001$ & $0.10 \pm 0.01$ & $0.10 \pm 0.01$ & $0.19 \pm 0.02$ & $0.30 \pm 0.05$ & $1.5 \pm 0.2$ & $0.17 \pm 0.01$ & $0.11 \pm 0.03$ & $0.10 \pm 0.01^{a, b}$ \\
\hline & $(0.42 \pm 0.02)^{a}$ & $(1.3 \pm 0.1)^{a}$ & $(1.23 \pm 0.09)^{a}$ & $(2.4 \pm 0.3)^{a}$ & $(2.7 \pm 0.6)^{b}$ & $(17 \pm 2)^{b}$ & $(1.9 \pm 0.2)^{a}$ & $(1.0 \pm 0.4)^{a}$ & \\
\hline \multirow{2}{*}{$\begin{array}{l}\text { Orthognathoterme } \\
\text { s sp } 2\end{array}$} & $4.5 \pm 0.4$ & $0.13 \pm 0.02$ & $0.6 \pm 0.1$ & $0.10 \pm 0.02$ & 0 & $0.17 \pm 0.03$ & $0.16 \pm 0.03$ & $0.020 \pm 0.005$ & $0.26 \pm 0.03^{d}$ \\
\hline & $(14 \pm 1)^{c, d, e}$ & $(0.42 \pm 0.07)^{a}$ & $(1.9 \pm 0.4)^{a}$ & $(0.32 \pm 0.07)^{a}$ & $(0)^{b}$ & $(1.2 \pm 0.2)^{a}$ & $(1.1 \pm 0.1)^{a}$ & $(0.38 \pm 0.09)^{a}$ & \\
\hline \multirow[t]{2}{*}{ C. silvestrii } & $2.3 \pm 0.3$ & $0.53 \pm 0.09$ & $0.57 \pm 0.06$ & $1.61 \pm 0.07$ & $0.23 \pm 0.03$ & $1.39 \pm 0.01$ & $2.67 \pm 0.03$ & $0.10 \pm 0.01$ & $0.14 \pm 0.01 b, c$ \\
\hline & $(19 \pm 2)^{d, e}$ & $(4.3 \pm 0.8)^{a}$ & $(4.6 \pm 0.6)^{a}$ & $(12.9 \pm 0.7)^{b}$ & $(1.5 \pm 0.2)^{b}$ & $(26 \pm 1)^{b, c}$ & $(44 \pm 5)^{b}$ & $(0.64 \pm 0.04)^{a}$ & \\
\hline \multirow[t]{2}{*}{ S. dirus } & $5.3 \pm 0.4$ & $0.9 \pm 0.3$ & $0.59 \pm 0.04$ & $0.26 \pm 0.06$ & $0.6 \pm 0.2$ & $9 \pm 1$ & $0.7 \pm 0.1$ & $0.16 \pm 0.04$ & $0.18 \pm 0.01^{c}$ \\
\hline & $(9 \pm 1)^{a, b, c, c, d}$ & $(2.3 \pm 0.4)^{a}$ & $(1.0 \pm 0.1)^{a}$ & $(0.4 \pm 0.1)^{a}$ & $(4 \pm 1)^{b}$ & $(25 \pm 4)^{b, c}$ & $(2.3 \pm 0.5)^{a}$ & $(2.1 \pm 0.7)^{a}$ & \\
\hline \multirow[t]{2}{*}{ N. jaraguae } & $0.56 \pm 0.07$ & $1.5 \pm 0.1$ & $0.80 \pm 0.04$ & $2.1 \pm 0.3$ & $0.17 \pm 0.04$ & $3.2 \pm 0.1$ & $0.4 \pm 0.1$ & $0.15 \pm 0.03$ & $0.040 \pm 0.003^{a}$ \\
\hline & $(8 \pm 1)^{a, b, c}$ & $(15 \pm 1)^{b, c}$ & $(20 \pm 1)^{c}$ & $(44 \pm 7)^{c}$ & $(3.8 \pm 0.5)^{b}$ & $(68 \pm 4)^{e}$ & $(9 \pm 1)^{a}$ & $(3.8 \pm 1.1)^{\mathrm{a}}$ & \\
\hline \multirow[t]{2}{*}{ N. bivalens } & $0.89 \pm 0.09$ & $1.5 \pm 0.3$ & $1.5 \pm 0.1$ & $3.15 \pm 0.05$ & $0.38 \pm 0.02$ & $1.9 \pm 0.2$ & $0.62 \pm 0.02$ & $0.140 \pm 0.005$ & $0.10 \pm 0.02^{a, b}$ \\
\hline & $(11 \pm 1)^{b, c, d}$ & $(20 \pm 3)^{c}$ & $(17 \pm 2)^{c}$ & $(37 \pm 1)^{c}$ & $(4 \pm 1)^{b}$ & $(32 \pm 2)^{b, c, d}$ & $(10.8 \pm 0.2)^{a}$ & $(1.5 \pm 0.4)^{\mathrm{a}}$ & \\
\hline
\end{tabular}

Figures are means \pm standard error of the mean. See Materials and methods for details. Statistical analysis (ANOVA) was carried out with SPSS 8.0. Specific activities for each substrate were compared across species. Each column was submitted to one-way ANOVA and pairs of figures were compared using Tukey's honestly significant difference test, with significance level of 0.05 . superscript letter are not significantly different. CMC: carboxymethylcellulose; CSCB: colloidal sugar cane bagasse; pnP $\beta$ Glu: $p$-nitrophenyl- $\beta$-glucoside; pNP $\beta$ Xyl: $p$-nitrophenyll $\beta$-xyloside. 
(Coptotermes gestroi and Heterotermes tenuis), had poor activities against CSCB (Table 2). Therefore, we tried to understand which kind of enzyme was responsible for the high hydrolytic capacities against CSCB in $S$. nigrostomus.

The ratio between the activities against cellulose and $\mathrm{CMC}$ has been used as an indicator of the presence of enzymes with binding domains that are able to recognize crystalline or insoluble forms of cellulose, such as cellobiohydrolases or specific (in many cases processive) endo- $\beta$-1,4-glucanases [13]. Strikingly, S. nigrostomus, the species with the highest activity against CSCB, had a low cellulose to CMC hydrolysis ratio when compared to other termites (Table 3$)$. Some termites $(H$. tenuis and C. gestroi) presented cellulose to CMC hydrolysis ratios that were higher than the commercial $T$. viride cellulase (Table 3) as well as high CSCB to CMC hydrolysis ratios, but they had the smallest CSCB to cellulose hydrolysis ratios. Additionally, S. nigrostomus had the highest CSCB to cellulose hydrolysis ratio (Table 3). Taken together, these facts suggest that components other than cellulases could be responsible for the hydrolysis of CSCB in these digestive systems.

To carry out a more detailed study, we compared the enzymatic activities of termites using CSCB and the commercial substrates. Specific activities against p-nitrophenyl- $\beta$-xyloside did not show positive correlation with activities against CSCB $(r=-0.35)$. Other activities showed low positive correlations with CSCB hydrolysis, but these were not statistically significant (laminarin, $\mathrm{r}=$ 0.33; CMC, $\mathrm{r}=0.34$; pectin, $\mathrm{r}=0.34$; xylan, $\mathrm{r}=0.21$; pnP $\beta$ Glu, $r=0.22$; cellulose, $r=0.13$ ). These results suggest that the concerted action of several enzymes could be determinant of the efficient hydrolysis of CSCB, rather than only one enzyme specificity. Nevertheless, we cannot discard the possible action of other hemicellulases, or synergistic effects between enzymes, to explain the high activity of S. nigrostomus against CSCB. There is an interesting parallel between the presence of litter from grasses in the diet of this insect and the hydrolysis against CSCB; this suggests that, for the hydrolysis of sugarcane material, the enzymes from wood feeding termites might not be the most interesting.

There has been an extensive increase in studies concerning termite hydrolytic enzymes and digestive physiology $[14,15]$. The isolation, characterization, cloning and expression of hydrolytic enzymes from these insects have already been reported $[16,17]$.The gut microbiota of some termite species has already been the subject of detailed transcriptomic and metagenomic studies [18-20], and several genes with biotechnological potential have been sequenced. In spite of this, the digestion physiology in termites is a poorly studied subject, considering that only a few cases from a group of 2,600 known species [21] have been subjected to any kind of biochemical study. Our findings show that termites are probably an important source for the discovery of new enzymes.

More importantly, our data clearly shows that screening with a natural substrate can result in enzymatic profiles quite different from those obtained with commercial cellulase substrates, such as CMC and crystalline cellulose. The choice of substrate that best represents the material to be used in the biodegradation processes can be of major importance for decision making in this field of biotechnological research.

\section{Conclusions}

We have shown that raw sugarcane bagasse can be transformed into a colloidal suspension of particles suitable for high throughput enzymatic assays. We also

Table 3 Ratio between activities against selected substrates in termites and $T$. reesei. Ratios and deviations were calculated using data from Tables 1 and 2.

\begin{tabular}{llll}
\hline Species & Cellulose/CMC & CSCB/CMC & CSCB/Cellulose \\
\hline Heterotermes tenuis & $19 \pm 3^{\mathrm{c}}$ & $3.1 \pm 0.8^{\mathrm{b}, \mathrm{c}, \mathrm{d}}$ & $0.16 \pm 0.03^{\mathrm{a}}$ \\
Coptotermes gestroi & $12 \pm 3^{\mathrm{b}, \mathrm{c}}$ & $3 \pm 1^{\mathrm{c}, \mathrm{d}}$ & $0.28 \pm 0.01^{\mathrm{a}}$ \\
Grigiotermes sp. & $0.14 \pm 0.05^{\mathrm{a}}$ & $0.28 \pm 0.06^{\mathrm{a}, \mathrm{b}}$ & $1.8^{\mathrm{a}} \pm 0.4^{\mathrm{a}}$ \\
Spinitermes nigrostomus & $0.19 \pm 0.03^{\mathrm{a}}$ & $1.1 \pm 0.3^{\mathrm{a}, \mathrm{b}, \mathrm{c}}$ & $6 \pm 1^{\mathrm{b}}$ \\
Microcerotermes strunckii & $2.0 \pm 0.3^{\mathrm{a}}$ & $0.7 \pm 0.2^{\mathrm{a}, \mathrm{b}}$ & $0.37^{\mathrm{a}} \pm 0.07^{\mathrm{a}}$ \\
Orthognathotermes sp 2 & $0^{\mathrm{a}}$ & $1.2 \pm 0.6^{\mathrm{a}, \mathrm{b}, \mathrm{c}}$ & - \\
Cornitermes silvestrii & $0.35 \pm 0.02^{\mathrm{a}}$ & $0.17 \pm 0.03^{\mathrm{a}}$ & $0.4 \pm 0.1^{\mathrm{a}}$ \\
Syntermes dirus & $6 \pm 2^{\mathrm{a}, \mathrm{b}}$ & $2.0 \pm 0.6^{\mathrm{a}, \mathrm{b}, \mathrm{c}, \mathrm{d}}$ & $1.3 \pm 0.6^{\mathrm{a}}$ \\
Nasutitermes jaraguae & $0.23 \pm 0.03^{\mathrm{a}}$ & $0.3 \pm 0.1^{\mathrm{a}, \mathrm{b}}$ & $1.2^{\mathrm{a}} \pm 0.4^{\mathrm{a}}$ \\
Nasutitermes bivalens & $0.23 \pm 0.07^{\mathrm{a}}$ & $0.08 \pm 0.02^{\mathrm{a}}$ & $0.36 \pm 0.02^{\mathrm{a}}$ \\
Trichoderma reesei & $1.98 \pm 0.08^{\mathrm{a}}$ & $4.25 \pm 0.08^{\mathrm{d}}$ & $2.14 \pm 0.05^{\mathrm{a}}$
\end{tabular}

Statistical analysis (ANOVA) was carried out with SPSS 8.0. Ratios between activities were compared across species. Each column was submitted to one-way ANOVA and pairs of figures were compared using Tukey's honestly significant difference test, with significance level of 0.05 . ${ }^{a, b, c, d}$ In a column, groups with the same superscript letter are not significantly different. CMC: carboxymethylcellulose; CSCB: colloidal sugar cane bagasse. 
found that screening of termite gut homogenates using a natural substrate identified a species, S. nigrostomus, with high activity against sugarcane bagasse. This highlights the important differences in screening using natural substrates compared with commercial cellulase substrates.

\section{Methods}

\section{Termites}

Adult workers were collected in the states of Rio de Janeiro (RJ) and Minas Gerais (MG), Brazil. Grigiotermes sp. and Cornitermes silvestrii were collected in the Parque Estadual do Sumidouro (latitude $-19.5615^{\circ}$, longitude $-43.9588^{\circ}$ ) in the municipality of Lagoa Santa (MG). Orthognathotermes sp 2 and S.nigrostomus were collected near the city of Lagoa Santa, and H. tenuis was collected inside a sugarcane silo also in this region (MG, latitude $-19.5804^{\circ}$, longitude $\left.-43.9498^{\circ}\right) . N$. bivalens was collected in the municipality of Laje do Muriaé (RJ, latitude $-21.2095^{\circ}$, longitude $-42.1281^{\circ}$ ). N. jaraguae, Microcerotermes strunckii and C. gestroi were collected in the FIOCRUZ campus (RJ, latitude - $22.8771^{\circ}$, longitude $-43.2432^{\circ}$ ). Syntermes dirus was collected in the campus of the Universidade Federal do Rio de Janeiro (RJ, latitude $-22.8432^{\circ}$, longitude $-43.2349^{\circ}$ ). Insects were identified in the field under a stereomicroscope, using Constantino's illustrated key [12], and 50 to 100 individuals from each species (including all developmental stages) were sent in ethanol $70 \%(\mathrm{v} / \mathrm{v})$ to the Isoptera Collection of the Universidade de Brasília (RC) for final identification and preservation.

\section{Preparation of samples}

Right after capture, insects were immobilized on ice and dissected in cold $0.25 \mathrm{M}$ sodium chloride. The entire gut was pulled apart and, after removal of the Malpighian tubes and fat body, tissues were rinsed with saline and frozen in liquid nitrogen. Five sets of forty animals were dissected for all but three species: $N$. jaraguae (three sets of forty individuals), $S$. dirus (five sets of thirteen individuals) and Orthognathotermes sp 2 (five sets of thirteen individuals). After transportation to the laboratory, samples were kept at $-20^{\circ} \mathrm{C}$.

Termite guts were homogenized in $1 \mathrm{~mL}$ (except for S. dirus, homogenized in $2 \mathrm{~mL}$ ) of double distilled water using a Potter-Elvehjem homogenizer with 10 strokes, and used directly on enzymatic assays.

\section{Preparation of CSCB}

Sugar cane bagasse was provided by an ethanol producer from the city of Campos dos Goytacazes (RJ). Forty grams of the bagasse were macerated in $200 \mathrm{~mL}$ of liquid nitrogen in a mortar. The resulting material was ground in an analytical mill (model Q298A21,
Quimis, Brazil, Diadema) with two periods of 1 minute, after which it was macerated again as described above and ground for a further minute. The material was then passed sequentially through three sieves (19 mesh/cm, 26 mesh/cm, US Standard and a circular mesh with $0.8 \mathrm{~mm}$ diameter holes, 121 holes $/ \mathrm{cm}^{2}$ ). Each fraction, with the different particle sizes, was separately milled in a ceramic ball mill (model 298-1, Quimis) with $400 \mathrm{~mL}$ of double distilled water. The resulting colloidal suspensions were then autoclaved and combined in proportion to the raw material in a laminar flow cabinet and, when needed, used directly in the enzymatic assays. All steps were monitored by quantifying total carbohydrates with the phenol-sulfuric method [22].

\section{Protein measurements and enzymatic assays}

Protein was determined with Coomassie Blue G using ovalbumin as a standard [23]. The activity against soluble polysaccharides and CSCB was determined by measuring the release of reducing groups with dinitrosalicylic acid [24] with $0.25 \%(\mathrm{w} / \mathrm{v})$ laminarin (from Laminaria digitata, Sigma Chemical Company, Saint Louis, MO, USA; catalogue number L9634), CMC, pectin (from apples, Fluka; catalogue number 76282) and xylan (from birch wood, Fluka; catalogue number 95588) or $0.21 \%(\mathrm{w} / \mathrm{v})$ CSCB. $\beta$-glucosidase and $\beta$-xylosidase activity were determined by measuring the release of 4-nitrophenolate [25] with $5 \mathrm{mM} 4$-nitrophenyl- $\beta$ glucoside and 4-nitrophenyl- $\beta$-xyloside, respectively. Cellulase activity was determined by measuring the release of reducing groups with bicinchoninic acid [26] with $0.25 \%(\mathrm{w} / \mathrm{v})$ crystalline cellulose (Sigma; catalogue number S5504). The CSCB and cellulose suspensions were maintained under shaking throughout the assay. All chemicals and substrates (except CSCB) and T. reesei crude cellulase (catalogue number C7377) were acquired from Sigma Chemical Company.

Unless otherwise specified, all substrates were assayed in $50 \mathrm{mM}$ citrate-sodium phosphate, $\mathrm{pH} 6.0$ at $30^{\circ} \mathrm{C}$ under conditions such that activity was proportional to protein concentration and time of incubation. Controls without enzyme or without substrate were included. One unit of enzyme (U) was defined as the amount that hydrolyzes $1 \mu \mathrm{mol}$ of bonds per minute.

\section{Analysis of particles in CSCB by transmission and scanning electron microscopy}

For transmission electron microscopy, a CSCB suspension obtained as described above was deposited in a copper grid covered with Formvar/Carbon film and analyzed in a FEI Tecnai Spirit 120 Microscope (FEI, Hillsboro, Oregon, USA), operating at $80 \mathrm{kV}$. Particle diameters were measured using the program Megaview 
3 Imagen System Analysis 3.1 (FEI, Hillsboro, Oregon, USA).

For scanning electron microscopy, samples were deposited onto a glass slide previously treated with polyL-lysine. The samples were then dehydrated using increasing concentrations of ethanol, dried with the Supercrytical Dryer Leica EM SCD 500 (LEICA, Wetzlar, Germany) and covered with $2 \mathrm{~nm}$ of gold in the Sputtering LEICA EM CPD 030 (LEICA, Wetzlar, Germany). Samples were then observed using the FEI Novananolab 600 (FEI, Hillsboro, Oregon, USA) operating at $2 \mathrm{kV}$.

\section{Abbreviations}

CMC: carboxymethylcellulose; CSCB: colloidal sugar cane bagasse; MG: Minas Gerais; pNPßGlu: p-nitrophenyl- $\beta$-glucoside; RJ: Rio de Janeiro; SEM: standard error of the mean.

\section{Acknowledgements}

This work was funded by the Brazilian research agencies Fundação de Amparo à Pesquisa do Estado do Rio de Janeiro (FAPERJ), Fundação Oswaldo Cruz, Conselho Nacional de Desenvolvimento Cientifico e Tecnologico (CNPq) and by Petrobas (CENPES). We are indebted to Prof. Walter Ribeiro Terra and Prof. Clélia Ferreira (both Universidade de São Paulo), for helpful discussions, and to Sebastião Bides Alves, for helping with the insect collection. PA, ESG, RC and WS are research fellows from CNPq. $S A L$ and $L S L$ received post-doctoral and technical grants, respectively, from the FAPERJ/INMETRO and CNPq/INMETRO (PROMETRO) programs.

\section{Author details}

'Directory of Programs; National Institute of Metrology, Quality and Technology; Avenida Nossa Senhora das Graças, 50 - Xerém, Duque de Caxias, 25250-020, Brazil. ²Zoology Department, University of Brasília, Campus Universitário Darcy Ribeiro - Instituto Central de Ciências Room AT-116, Brasília, 70910-900, Brazil. ${ }^{3}$ Laboratory of Insect Biochemistry and Physiology, Oswaldo Cruz Institute, Avenida Brasil 4365, Leônidas Deane Building Room 207, Rio de Janeiro, 21040-360, Brazil. ${ }^{4}$ Department of Molecular Entomology, National Institute of Science and Technology, Avenida Brigadeiro Trompowsky, Centro de Ciências da Saúde, Building D-SS room 05, Rio de Janeiro, 21941-590, Brazil.

\section{Authors' contributions}

SAL, LSL and FAG carried out the CSCB preparations, collection and preparation of termite samples and biochemical assays. LSAC and CS carried out the transmission and scanning electron microscopy experiments and data analysis. FAG and SAL analyzed the biochemical data. RC identified the termites and participated in the discussion of termite ecology and physiology. FAG, SAL, PA, WS and ESG conceived the study and designed the experiments. FAG drafted the manuscript, with the help of SAL and CS. All authors read and approved the final manuscript.

\section{Competing interests}

The CSCB preparation was deposited in the National Institute of Industrial Property of Brazil (INMETRO; patent number 020110064559). This work was partially funded by Petrobas (Centro de Pesquisa e Desenvolvimento Leopoldo A Miguez de Mello; CENPES) and the National Institute of Metrology, Quality and Technology, which hold the patent rights together with SAL, WS, ESG and FAG.

Received: 6 September 2011 Accepted: 14 November 2011 Published: 14 November 2011

\section{References}

1. Klemm D, Schmauder H-P, Heinze T: Cellulose. Biopolymers Online 2005.

2. Anonymous: Kill king corn. Nature 2007, 449:637.
3. Goldemberg J: Ethanol for a sustainable energy future. Science 2007, 315:808-810.

4. Nass LL, Pereira PAA, Ellis D: Biofuels in Brazil: an overview. Crop Sci 2007, 47:2228-2237.

5. Soccol CR, Vandenberghe LPD, Medeiros ABP, Karp SG, Buckeridge M Ramos LP, Pitarelo AP, Ferreira-Leitao V, Gottschalk LMF, Ferrara MA, Bon EPD, de Moraes LMP, Araujo JD, Torres FAG: Bioethanol from lignocelluloses: status and perspectives in Brazil. Bioresource Technol 2010, 101:4820-4825.

6. Balat $\mathrm{M}, \mathrm{Balat} \mathrm{H}, \mathrm{Oz} \mathrm{C}$ : Progress in bioethanol processing. Progress in Energy and Combustion Science 2008, 34:551-573.

7. Chundawat SPS, Balan V, Dale BE: High-throughput microplate technique for enzymatic hydrolysis of lignocellulosic biomass. Biotechnol Bioengin 2008, 99:1281-1294.

8. Oppert C, Klingeman WE, Willis JD, Oppert B, Jurat-Fuentes JL: Prospecting for cellulolytic activity in insect digestive fluids. Comp Biochem Physiol B Biochem Mol Biol 2010, 155:145-154.

9. Decker SR, Brunecky R, Tucker MP, Himmel ME, Selig MJ: High-throughput screening techniques for biomass conversion. Bioenergy Res 2009, 2:179-192.

10. National Institute of Standards \& Technology, USA: Sugarcane Bagasse Whole Biomass Feedstock Report of Investigation. RM8491 2011, 1-4.

11. Esterbauer H, Steiner W, Labudova I, Hermann A, Hayn M: Production of Trichoderma cellulase in laboratory and pilot scale. Bioresource Technol 1991, 36:51-65.

12. Constantino R: Chave ilustrada para a identificação dos gêneros de cupins (Insecta: Isoptera) que ocorrem no Brasil. Papéis Avulsos de Zoologia 1999, 40:387-448.

13. Dashtban M, Maki M, Leung KT, Mao C, Qin W: Cellulase activities in biomass conversion: measurement methods and comparison. Critical Rev Biotechnol 2010, 30:302-309.

14. Sharf ME, Boucias DG: Potential of termite-based biomass pre-treatment strategies for use in bioethanol production. Insect Sci 2010, 17:166-174

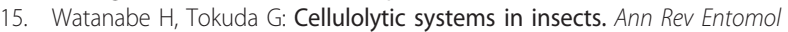
2010, 55:609-632.

16. Zhang DH, Lax AR, Raina AK, Bland JM: Differential cellulolytic activity of native-form and C-terminal tagged-form cellulase derived from Coptotermes formosanus and expressed in E. coli. Insect Biochem Mol Biol 2009, 39:516-522.

17. Todaka N, Lopez CM, Inoue T, Saita K, Maruyama J, Arioka M, Kitamoto K, Kudo T, Moriya S: Heterologous expression and characterization of an endoglucanase from a symbiotic protist of the lower termite, Reticulitermes speratus. Appl Biochem Biotechnol 2010, 160:1168-1178.

18. Tartar A, Wheeler MM, Zhou XG, Coy MR, Boucias DG, Scharf ME: Parallel metatranscriptome analyses of host and symbiont gene expression in the gut of the termite Reticulitermes flavipes. Biotechnol Biofuels 2009, 2:19.

19. Warnecke F, Luginbuhl P, Ivanova N, Ghassemian M, Richardson TH, Stege JT, Cayouette M, McHardy AC, Djordjevic G, Aboushadi N, Sorek R, Tringe SG, Podar M, Martin HG, Kunin V, Dalevi D, Madejska J, Kirton E, Platt D, Szeto E, Salamov A, Barry K, Mikhailova N, Kyrpides NC, Matson EG, Ottesen EA, Zhang XN, Hernandez M, Murillo C, Acosta LG, Rigoutsos I, Tamayo G, Green BD, Chang C, Rubin EM, Mathur EJ, Robertson DE, Hugenholtz P, Leadbetter JR: Metagenomic and functional analysis of hindgut microbiota of a wood-feeding higher termite. Nature 2007 450:560-565.

20. Yuki M, Moriya S, Inoue $\mathrm{T}$, Kudo $\mathrm{T}$ : Transcriptome analysis of the digestive organs of Hodotermopsis sjostedti, a lower termite that hosts mutualistic microorganisms in its hindgut. Zoolog Sci 2008, 25:401-406.

21. Egglelton P: An introduction to termites: biology, taxonomy and functional morphology. In Biology of termites: a modern synthesis. Edited by: Bignell DE, Roisin Y, Lo N. New York: Springer; 2010:1-26.

22. Dubois M, Gilles KA, Hamilton JK, Rebers PA, Smith F: Colorimetric method for determination of sugars and related substances. Anal Chem 1956, 28:350-356.

23. Bradford M: A rapid and sensitive method for the quantitation of microgram quantities of protein utilizing the principle of protein-dye binding. Anal Biochem 1976, 72:248-254.

24. Noelting G, Bernfeld P: Sur les enzymes amylolitiques. 3. La beta amylase - dosage d'activite et controle de l'absence d'alpha-amylase. Helv Chim Acta 1948, 31:286-290. 
25. Terra WR, Ferreira C, Bianchi AGD: Distribution of digestive enzymes among the endoperitrophic and midgut cells of Rhynchosciara and its physiological significance. J Insect Physiol 1979, 25:487-494.

26. Vlasenko EY, Ryan Al, Shoemaker CF, Shoemaker SP: The use of capillary viscometry, reducing end-group analysis, and size exclusion chromatography combined with multi-angle laser light scattering to characterize endo-1,4-beta-D-glucanases on carboxymethylcellulose: a comparative evaluation of the three methods. Enzyme Microbial Technol 1998, 23:350-359.

doi:10.1186/1754-6834-4-51

Cite this article as: Lucena et al:: High throughput screening of

hydrolytic enzymes from termites using a natural substrate derived from sugarcane bagasse. Biotechnology for Biofuels 2011 4:51.

\section{Submit your next manuscript to BioMed Central} and take full advantage of:

- Convenient online submission

- Thorough peer review

- No space constraints or color figure charges

- Immediate publication on acceptance

- Inclusion in PubMed, CAS, Scopus and Google Scholar

- Research which is freely available for redistribution

Submit your manuscript at www.biomedcentral.com/submit
C Biomed Central 